\title{
TINDAK PIDANA KEKERASAN TERHADAP ANAK YANG MENYEBABKAN KEMATIAN DILAKUKAN OLEH IBU KANDUNGNYA
}

\author{
Oleh \\ Rommy Pratama (rommy.fh@unis.ac.id)*) \\ Irma Rahmayanti (irmarahma12298@gmail.com)
}

\section{Abstrak}

Anak merupakan tunas penerus bangsa yang harus dijaga dan dilindungi. Setiap anak yang lahir seharusnya mendapatkan perlindungan dan kasih sayang dari kedua orang tuanya. Namun pada kenyataannya tidak sedikit dari orang tua yang tidak peduli terhadap anak kandungnya sendiri. Banyak sekali kasus kekerasan dan pembunuhan anak yang dilakukan oleh orang tuanya sendiri. Tindak pidana kekerasan terhadap anak yang menyebabkan kematian dilakukan oleh ibu kandungnya merupakan suatu tindak pidana yang tidak berperikemanusiaan. Permasalahan dalam penelitian ini adalah apakah yang menyebabkan ibu kandung melakukan tindak pidana kekerasan terhadap anak baru lahir yang menyebabkan kematian dan bagaimana penerapan sanksi pidana terhadap pelaku tindak pidana kekerasan terhadap anak baru lahir yang menyebabkan kematian. Tipe penelitian yuridis empiris, sifat penelitian deskriptif analisis. Adapun hasil kesimpulan penulis ialah penyebab ibu kandung melakukan tindak pidana kekerasan terhadap anak baru lahir yang menyebabkan kematian karena faktor rasa malu karena mengandung dan melahirkan bayi diluar pernikahan dan rasa kesal terhadap ayah biologis korban yang tidak mau bertanggung jawab dan penerapan sanksi terhadap ibu kandung bayi tersebut sudah sesuai dengan unsur-unsur yang ada dalam pasal 80 ayat 3 dan 4 jo pasal $76 C$ Undang-Undang Nomor 35 Tahun 2014 tentang Perlindungan Anak. Adapun sarannya harus adanya sex education, harus adanya hubungan yang lebih erat dengan keluarga untuk saling mengingatkan akan hal baik dan hal buruk, harus adanya kesadaran dari diri masyarakat untuk berfikir terlebih dahulu sebelum bertindak.

\section{Kata Kunci : Tindak Pidana, Kekerasan Anak, Perlindungan Anak}

\section{A.PENDAHULUAN}

Di Indonesia telah ditetapkan banyak peraturan guna mengatur segala tingkah laku manusia dalam kehidupan seharihari. Setiap warga negara wajib menaati peraturan yang telah ditetapkan. Karena pada dasarnya setiap manusia pasti akan melakukan kesalahan yang disengaja maupun tidak disengaja. Segala bentuk perbuatan yang melanggar aturan akan dikenakan sanksi oleh pihak berwajib dan

*) Penulis adalah Dosen Fakultas Hukum Universitas Islam Syekh Yusuf harus mampu mempertanggungjawabkan segala perbuatannya.

Setiap anak yang lahir seharusnya mendapatkan perlindungan dan kasih sayang dari kedua orang tuanya. Seperti peribahasa yang mengatakan "sebuasbuasnya harimau ia tidak akan memakan anaknya sendiri" yang memiliki arti bahwa tidak ada orang tua yang tega mencelakakan anaknya sendiri. Namun pada kenyataannya tidak sedikit dari orang tua yang tidak peduli terhadap anak kandungnya sendiri, tak jarang pula 
mereka menelantarkan bahkan melakukan perbuatan yang tidak berperikemanusiaan terhadap anak kandungnya.

Anak merupakan anugerah terindah yang Allah SWT titipkan kepada manusia untuk dijaga dan dicintai dengan sepenuh hati. Anak termasuk rezeki yang Allah SWT berikan pada setiap keluarga. Setiap pasangan yang menikah pasti menginginkan dikaruniai seorang anak. Anak merupakan tunas penerus bangsa yang harus dijaga dan dilindungi. Menurut undang-undang perlindungan anak Nomor 35 Tahun 2014 tentang Perubahan Undang-Undang Perlindungan Anak Nomor 23 Tahun 2002 anak adalah seseorang yang belum berusia 18 (delapan belas) tahun, termasuk anak yang masih dalam kandungan. Setiap anak yang lahir memiliki hak untuk hidup dan berkembang hingga anak tumbuh menjadi dewasa sehingga sebagai bentuk hak asasi manusia.

Sering kita lihat berita di televisi, sosial media, koran dan lain-lain tentang pembuangan seorang bayi, baik yang masih bernyawa maupun yang sudah tidak bernyawa. Bayi yang tak bernyawa dibuang ditempat sampah, disungai, disemak-semak dan di tempat lainnya, dan pelakunya tak lain adalah ibu kandungnya sendiri. Pembunuhan semacam ini dilakukan saat bayi dilahirkan atau beberapa saat setelah bayi lahir.

Bila setiap anak yang lahir mendapatkan perbuatan yang melanggar hakhak atas dirinya maka akan mendapat ancaman hukuman sesuai ketentuan yang sudah berlaku seperti yang telah diatur dalam Undang-Undang perlindungan anak Nomor 35 Tahun 2014. Menurut Undang-Undang Dasar di dalam Pasal 28A Undang-Undang Dasar 1945 berbunyi "Setiap orang berhak untuk hidup serta berhak mempertahankan hidup dan kehidupannya".

Kekerasan termasuk dalam perbuatan tindak pidana yang bisa menyebabkan seseorang mengalami luka bahkan hilangnya nyawa seseorang. Setiap bentuk kekerasan yang mengakibatkan hilangnya nyawa seseorang harus ditegakkan hukumnya. Anak menjadi obyek yang rentan terjadinya perbuatan kekerasan oleh orang dewasa karena anak adalah makhluk yang lemah. Hukuman bagi pelaku tindak pidana kekerasan terhadap bayi yang menyebabkan kematian diatur dalam Undang-Undang perlindungan anak Nomor 35 Tahun 2014 Pasal 76C yang berbunyi : "Setiap orang dilarang menempatkan, membiarkan, melakukan, menyuruh melakukan, atau turut serta melakukan kekerasan terhadap anak".

Pembunuhan merupakan suatu tindak pidana yang menyebabkan hilangnya nyawa seseorang yang dilakukan dengan sengaja terhadap seseorang. Banyak faktor yang menyebabkan seseorang melakukan tindak pidana pembunuhan terhadap seorang bayi. Karena faktor tidak siapnya seseorang menjadi seorang ibu, tidak siap dalam segi ekonomi, atau karena seseorang itu malu karena melahirkan seorang bayi diluar pernikahan dan lainlain. Semua itu menjadi salah satu alasan seseorang membunuh seorang bayi yang tidak berdosa.

Tindak pidana pembunuhan bayi (infanticide) adalah sebuah tindak pidana khusus, dimana yang bisa melakukannya adalah ibu kandung dari bayi tersebut. Kekhususan inilah yang akan menjadi inti dari penulisan ini, mengkaji hal yang yang menjadi faktor-faktor penyebab tindak pidana ini dilakukan karena hal tersebut menjadi kekhususan tindak pidana ini. ${ }^{1}$ Infanticide atau pembunuhan anak ini dilakukan oleh ibu kandungnya terhadap anak kandung yang berumur dibawah 12 bulan. Maraknya kasus

1 Fuadi Isnawan, "Analisa tindak pidana pembunuhan bayi (infanticide) di wilayah hukum pengadilan negeri sleman", Jurnal Yuridis Vol. 5 No. 1, (2018), 23-42 
pembunuhan bayi yang baru lahir meresahkan banyak warga. Perbuatan seorang ibu kandung yang dengan teganya membunuh anaknya yang baru lahir merupakan suatu perbuatan yang tidak berperikemanusiaan. Anak darah dagingnya sendiri yang tidak berdosa dengan teganya dibunuh.

Sudah tidak asing lagi sepertinya jika mendengar tentang pembunuhan bayi yang baru lahir oleh ibu kandungnya sendiri. Kasus semacam ini sangat sering terjadi di Indonesia. Tindakan semacam ini jelas sangat melanggar norma agama, hukum dan norma sosial kemasyarakatan pun meresahkan warga sekitar.

Seperti kasus yang akan penulis uraikan yaitu kekerasan terhadap seorang bayi yang menyebabkan kematian oleh ibu kandungnya sendiri. penulis mengangkat tentang kejahatan yang saat ini menjadi salah satu kejahatan yang paling "disukai" orang, selain aborsi. Kejahatan yang dimaksud yaitu kejahatan terhadap nyawa dalam hal ini objeknya ialah bayi yang dibunuh sedangkan pelakunya adalah ibu dari si bayi tersebut pada saat atau tidak lama setelah dilahirkan. 2 Hukum harus ditegakkan agar memberi efek jera pada pelaku

Seperti yang telah penulis uraikan pada latar belakang di atas, maka permasalahan dalam penelitian ini sebagai berikut:

1. Faktor-faktor apakah yang melatarbelakangi seorang ibu kandung melakukan tindak pidana kekerasan terhadap anak baru lahir yang menyebabkan kematian

2. Bagaimanakah penerapan sanksi pidana terhadap pelaku tindak pidana kekerasan terhadap anak baru lahir yang menyebabkan kematian?

2 Nindy N. Bowonsili, "Penerapan Sanksi Terhadap Ibu Sebagai Pelaku Tindak Pidana Pembunuhan Anak", Lex Crimen Vol. IV/No. 7/Sep/2015, hlm 43.

\section{B. PEMBAHASAN}

\section{Faktor-Faktor Seorang Ibu Kandung Melakukan Tindak Pidana Kekerasan Terhadap Anak Baru Lahir Yang Menyebabkan Kematian}

Ada banyak sekali bentuk dan macam kejahatan dalam kehidupan sehari-hari. Teori Sosial menjelaskan bahwa perilaku kejahatan adalah hasil kerusakan sistem dan struktur sosial. Seorang penjahat dari keluarga yang bercerai, mengalami masa kecil yang sulit, hidup di lingkungan sosial yang miskin dan banyak terjadi pelanggaran hukum, tidak memiliki pendidikan yang baik, memiliki gangguan fisik dan mental dan berbagai kesulitan psikososial lainnya. Dalam perspektif ini, kesannya individu dilihat sebagai pasif bentukan sistem di sekelilingnya. ${ }^{3}$

Dalam pembukaan Undang-Undang Dasar Negara Republik Indonesia Tahun 1945 bahwa setiap warga negara Indonesia harus melindungi segenap bangsa Indonesia dan seluruh tumpah darah Indonesia dan untuk memajukan kesejahteraan umum, mencerdaskan kehidupan bangsa, dan ikut melaksanakan ketertiban dunia yang berdasarkan kemerdekaan, perdamaian abadi dan keadilan sosial. Jadi setiap orang harus melindungi segala bentuk hak asasi mansuia yang pada dasarnya untuk melindungi hak-hak seseorang, termasuk hak seorang anak untuk tumbuh dan berkembang karena anak adalah pewaris dan tunas penerus bangsa.

Fenomena maraknya kasus pembunuhan bayi yang baru lahir (infanticide) merupakan perbuatan yang tidak berperikemanusiaan. Semakin rapuh akal budi, hati nurani lemahnya keimanan dalam diri seseorang dan kurangnya pengetahu-

3 https://psikologi.unair.ac.id/en_US/ artikelmengapa-orang-melakukan-kejahatan/, diakses pada tanggal 07 Agustus 2020 jam $21: 42$ 
an agama. Karena sejatinya setiap anak harus mendapatkan hak-hak atas diri mereka. Adapun kasus ini diatur dalam pasal dalam pasal 80 ayat 3 (tiga) dan 4 (empat) yang dihubungkan dengan pasal 76 C Undang-undang Nomor 35 Tahun 2014 tentang Perubahan kedua atas Undang-undang Nomor 23 Tahun 2002 tentang perlindungan anak yang menyatakan :

Pasal 80 ayat 3 (tiga) :

"Dalam hal Anak sebagaimana dimaksud pada ayat (2) mati, maka pelaku dipidana dengan pidana penjara paling lama 15 (lima belas) tahun dan/atau denda paling banyak Rp3.000.000.000,00 (tiga miliar rupiah)".

Pasal 80 ayat 4 (empat) :

"Pidana ditambah sepertiga dari ketentuan sebagaimana dimaksud pada ayat (1), ayat (2), dan ayat (3) apabila yang melakukan penganiayaan tersebut Orang Tuanya".

Pasal 76C :

"Setiap Orang dilarang menempatkan, membiarkan, melakukan, menyuruh melakukan, atau turut serta melakukan Kekerasan terhadap Anak".

Adapun hasil analisis faktor-faktor yang melatarbelakangi seorang ibu kandung melakukan tindak pidana kekerasan terhadap anak baru lahir yang menyebabkan kematian ialah sebagai berikut :

1. Alasan adanya rasa malu karena melahirkan diluar pernikahan, penyebab seorang ibu kandung melakukan pembunuhan terhadap anak dikarenakan seseorang itu malu melahirkan seorang bayi tanpa ayah atau melahirkan anak diluar perkawinan yang sah. Melahirkan seorang bayi diluar pernikahan itu merupakan suatu peristiwa yang sangat memalukan, suatu peristiwa yang dilarang oleh agama dan suatu peristiwa yang dihindari oleh setiap orang karena memalukan dan menjadi aib bagi keluarga. Selama proses mengandung si ibu tidak ditemani oleh ayah kandung si bayi atau dengan kata lain tidak bertanggung jawab sehingga si ibu menutupi kehamilannya dari orang-orang sekitar.

2. Adanya rasa takut ketahuan melahirkan anak karena si anak yang tidak diinginkan kehadirannya dan merupakan hasil dari hubungan gelap atau hubungan diluar pernikahan.

3. Tidak terkontrolnya tingkat mental emosional si ibu. Selain rasa malu dan rasa takut, tingkat mental emosional si ibu menjadi faktor terjadinya tindak pidana pembunuhan bayi yang baru lahir. Adanya rasa cemas, takut, bingung sehingga perbuatan itu dilakukan tanpa disadari. Kemudian dengan adanya rasa kesal tehadap ayah kandung si bayi yang tidak mau mempertanggungjawabkan perbuatannya menjadi faktor pendorong si ibu melakukan perbuatan yang tidak berperikemanusiaan.

4. Alasan ketidaksiapan seseorang menjadi seorang ibu untuk menerima hadirnya seorang anak dalam kehidupannya. Alasan ini membuat seorang ibu mengambil jalan pintas untuk membunuh anak kandungnya apalagi bayi yang ada dalam kandungannya merupakan hasil dari hubungan diluar pernikahan.

5. Alasan dari segi ekonomi, menjadi salah satu alasan penyebab seorang ibu membunuh bayi yang baru lahir. Merasa keadaan ekonomi tidak memungkinkan untuk memenuhi kebutuhan dirinya dan si buah hati. Untuk memenuhi kebutuhan dirinya sendiri saja kurang atau pas-pasan apalagi biaya tambahan untuk memenuhi kebutuhan anaknya untuk biaya makan pendidikan dan lain-lain sehingga membuat tekanan pada diri 
si ibu sehingga melakukan tindak pidana tersebut.

6. Dari segi pendidikan, minimnya pengetahuan membuat seseorang tidak berfikir panjang atas apa yang ia lakukan. Pendidikan sangat berpengaruh karena akan membentuk karakter dan pola piker seseorang. Kurangnya dan minimnya pengetahuan akan membuat seseorang tidak berfikir panjang dampak apa yang akan ia dapatkan setelah melakukan kejahatan. Pendidikan bisa kita dapatkan tidak hanya dari suatu lembaga pendidikan namun bisa dari keluarga kita sendiri. Keluarga merupakan awal mula pendidikan dimulai dan awal mula kita dibentuk. Orang tua akan mengajarkan kita mana hal yang baik dan mana hal yang buruk.

7. Dari segi agama, minimnya ilmu pengetahuan dan keimanan dalam diri membuat seseorang melakukan tindakan yang sangat dilarang oleh agama. Seperti melakukan kekerasan, pembunuhan, melakukan hubungan suami istri di luar pernikahan merupakan hal yang sangat dilarang oleh agama. Menurut Stephen Heurwitz, "Kepercayaan hanya dapat berlaku sebagai suatu anti krimogemis bila dihubungkan dengan pengertian dan perasaan moral yang telah meresap secara menyeluruh. Dan kepercayaan tidak boleh berubah dari sikap hidup moral keagamaan, merosot menjadi hanya suatu tata cara dan bentukbentuk lahiriah oleh orang dengan tasbeh di satu tangan, sedang tangan lainnya menusuk dengan pisau. Meskipun adanya faktor-faktor negative demikian, memang merupakan fakta bahwa norma-norma etis yang secara teratur diajarkan oleh bimbingan agama dan khususnya berambung pada keyakinan keagamaan yang sungguh, membangunkan secara khusus dorongan-dorongan yang kuat untuk melawan kecenderungankecenderungan kriminil". ${ }^{4}$

Selain hal tersebut diatas, ada faktor lain yang menyebabkan orang tua membunuh anaknya sendiri, yaitu $:^{5}$

1. faktor intern yaitu penyebab kejahatan yang berasal dari dalam diri pelaku tersebut, salah satunya adalah kejahatan yang lebih menekankan pada unsur psikologis, hal ini menekankan pada psikosis yang diakibatkan karena gangguan mental pelaku. Menurut Galles, ketidakmampuan dalam pengasuhan dan masalah kepribadian orangtua juga disebut Gelles sebagai faktor yang menyebabkan seseorang melakukan kekerasan terhadap anak-anaknya, orangtua yang melakukan kekerasan seringkali memiliki harapan yang tidak realistis pada anak mereka, memiliki pengetahuan yang minim mengenai perkembangan anak dan menunjukkan ketidakmampuan dalam menjalin hubungan dengan anak, selain itu mereka juga seringkali memiliki harga diri yang rendah dan kepribadian tidak matang, kurang rasa empati dan lebih egois, tingkat stress yang tinggi disebut juga dapat mempengaruhi tingkat kekerasan yang dilakukan orangtua sebagai coping terhadap stressnya tersebut (Firda Fauziah, 2012 : 18).

2. Faktor ekstern yaitu faktor yang berasal dari luar diri pelaku tersebut seperti keadaan lingkungan disekitar pelaku yang menyebabkan pelaku tega melakukan pembunuhan. Dalam hal ini secara subjektif bisa saja

${ }^{4}$ Stephen Hurwitz, Kriminologi, Alih Bahasa: L. Moeljatno, Jakarta: PT Bina Aksara, 1986, hlm 25.

5 Mayang Pantai Ayu Ningrum, Budi Setiyanto, Recidive Vol 3 No 2 Mei-Agustus 2014, "Analisis Tindak Pidana Pembunuhan Anak", hlm136-137. 
seorang anak yang dibunuh tidak memiliki kesalahan apa-apa atau tidak menyebabkan orangtua melakukan pembunuhan, tetapi anak ini hanya menjadi korban dari perilaku orangtua yang lepas kontrol emosi, atau bisa saja seorang anak lah yang menyebabkan orangtua melakuan pembunuhan.

Berdasarkan uraian yang telah penulis jabarkan di atas maka faktor yang menyebabkan seorang ibu melakukan tindak pidana kekerasan terhadap anak yang menyebabkan kematian dalam kasus Putusan Nomor: 44/pid.B/2018/ PN.Bta ialah karena faktor rasa malu yang mendalam yang dirasakan oleh terdakwa dikarenakan mengandung diluar perkawinan dan rasa kesal karena lakilaki yang telah menghamilinya tidak mau bertanggung jawab. Perasaan khawatir akan aib yang ditanggungnya karena hamil di luar pernikahan menjadi sebab seorang ibu melakukan tindakan yang tidak berperikemanusiaan. Adanya rasa cemas, takut, bingung yang berlebihan sehingga mendorong si terdakwa untuk melakukan tindak pidana membunuh bayinya.

Kemudian kurangnya pendidikan dan kesadaran hukum dalam diri masyarakat karena kita tahu bahwa berhubungan suami istri di luar pernikahan itu perbuatan yang sangat dilarang oleh agama dan hukum. Karena sejatinya pendidikan itu sangat penting untuk membentuk pola piker pada manusia. Bagaimana kita harus menyelesaikan suatu masalah dan tindakan apa yang harus kita lakukan. Kurangnya pengetahuan akan hukum yang berlaku di suatu negara membuat seseorang tidak berfikir panjang bahwa yang ia lakukanmerupakan perbuatan yang melanggar hukum dan harus dipertanggung jawabkan sesuai hukum yang berlaku.

\section{Penerapan Sanksi Pidana Terhadap Pelaku Tindak Pidana Kekerasan Terhadap Anak Yang Menyebabkan Kematian}

Sanksi menurut Kamus Besar Bahasa Indonesia merupakan tanggungan (tindakan atau hukuman) untuk memaksa orang menepati perjanjian atau menaati ketentuan undang-undang (anggaran dasar, perkumpulan, dan sebagainya); tindakan (mengenai perekonomian) sebagai hukuman kepada suatu negara; Hukum, a imbalan negatif, berupa pembebanan atau penderitaan yg ditentukan dalam hukum; b imbalan positif, yg berupa hadiah atau anugerah yg ditentukan dalam hukum. ${ }^{6}$

Sanksi pidana merupakan jenis sanksi yang bersifat nestapa yang dijatuhkan kepada pelaku tindak pidana yang melanggar aturan hukum yang berlaku. Sanksi pidana adalah penderitaan atau nestapa yang dibebankan kepada orang yang melakukan perbuatan yang memenuhi unsur-unsur syarat tertentu, sedangkan Roeslan Saleh menegaskan bahwa pidana dalah reaksi atas delik, dan berwujud nestapa yang dengan sengaja dilimphkan Negara kepada pembuat. 7 Menurut Richard D. Schwartz Dan Jerome H. Skonlick sanksi pidana dimaksudkan untuk: ${ }^{8}$

1. Mencegah terjadinya pengulangan tindak pidana (to prevent recidivism)

2. Mencegah orang melakukan perbuatan yang sama seperti yang dilakukan oleh terpidana (to deterother from the performance of similar acts)

6 Kamus Besar Bahasa Indonesia, 1995, Jakarta: Balai Fustaka, hlm 1265.

7 Tri Andrisman, Asas-Asas Dan Dasar Aturan Hukum Pidana Indonesia, Bandar Lampung: Ula, 2009, hlm 8.

8 Muladi Dan Barda Nawawi Arief, teori-teori dan kebijakan pidana, Bandung: Alumni, 1992, hlm 20. 
3. Menyediakan saluran untuk mewujudkan motif-motif balas dendam (to provide a channel for the expression of retaliatory motives).

Kekerasan merupakan perbuatan tindak pidana yang dapat menyebabkan seseorang mengalami luka atau bahkan hilangnya nyawa seseorang. Anak menjadi obyek yang rentan terjadinya perbuatan kekerasan oleh orang dewasa karena anak adalah makhluk yang lemah. Kekerasan terhadap anak yang menyebabkan kematian diatur dalam Undangundang Nomor 35 Tahun 2014 tentang Perubahan kedua atas Undang-undang Nomor 23 Tahun 2002 tentang Perlindungan anak, yaitu sebagai berikut :

Pasal 76C :

"Setiap Orang dilarang menempatkan, membiarkan, melakukan, menyuruh melakukan, atau turut serta melakukan kekerasan terhadap anak".

Pasal 80 ayat 3 (tiga) :

"Dalam hal Anak sebagaimana dimaksud pada ayat (2) mati, maka pelaku dipidana dengan pidana penjara paling lama 15 (lima belas) tahun dan/atau denda paling banyak Rp3.000.000.000,00 (tiga miliar rupiah)".

Pasal 80 ayat 4 (empat) :

"Pidana ditambah sepertiga dari ketentuan sebagaimana dimaksud pada ayat (1), ayat (2), dan ayat (3) apabila yang melakukan penganiayaan tersebut Orang Tuanya".

Berdasarkan uraian yang telah penulis jabarkan maka penerapan sanksi terhadap pelaku tindak pidana kekerasan terhadap anak yang menyebabkan kematian sudah sesuai dan memenuhi kriteria atau unsur-unsur,yang ada pada pasal Pasal 80 Ayat (3) dan (4) Jo Pasal 76 C UU Nomor 35 Tahun 2014 tentang Perubahan Kedua atas UU No.23 Tahun 2002 tentang Perlindungan Anak.

\section{PENUTUP}

Dari uraian-uraian tersebut penulis dapat memberikan kesimpulan sebagai berikut :

1. Faktor-faktor yang melatarbelakangi terjadinya tindak pidana kekerasan terhadap anak yang menyebabkan kematian ialah karena faktor rasa malu karena terdakwa harus mengandung anak di luar pernikahan. Terdakwa merasa malu kepada masyarakat atas aib kehamilannya tersebut. Terdakwa sengaja meninggalkan bayi tersebut dikarnakan terdakwa merasa kesal terhadap sdr. Ratno (ayah biologis korban) yang telah meninggalkan terdakwa dan tidak mau bertanggung jawab terhadap terdakwa yang sedang hamil sedangkan pada saat hamil saksi masih menjadi tani upahan jagung sampai terdakwa kesakitan melahirkan anaknya seorang diri.

2. Berdasarkan putusan nomor: 44/ pid.B/2018/PN.Bta bahwa terdakwa yaitu Wati binti Basri telah memenuhi unsur-unsur dari pasal pasal 80 ayat 3 (tiga) dan 4 (empat) yang dihubungkan dengan pasal 76 C Undangundang Nomor 35 Tahun 2014 tentang Perubahan kedua atas Undang-undang Nomor 23 Tahun 2002 tentang Perlindungan Anak.

Menimbang, bahwa karena terdakwa telah terbukti menurut hukum dan dinyatakan bersalah serta dijatuhi pidana, maka menurut pasal 222 ayat (1) KUHAP kepadanya harus pula dibebani untuk membayar biaya dalam perkara ini :

menimbang, bahwa sebelum menjatuhkan pidana dalam perkara ini kepada terdakwa perlu dipertimbangkan hal-hal yang memberatkan maupun hal-hal yang meringankan yang terdapat didalam maupun diluar diri terdakwa sebagai mana telah 
ditentukan dalam pasal 27 ayat ( 2 ) Undang-Undang Nomor : 14 Tahun 1970 jo Undang-Undang Nomor : 35 Tahun 1999 jo Undang - Undang Nomor : 4 Tahun 2004 jo pasal 197 ayat ( 1 ) huruf $\mathrm{f}$ KUHAP

Hal-hal yang memberatkan :

- Perbuatan terdakwa meresahkan masyarakat

- Terdakwa menghilangkan nyawa orang lain

- Korban merupakan anak kandung terdakwa

Hal-hal yang meringankan :

- Terdakwa belum pernah dihukum.

- Terdakwa berlaku sopan didalam persidangan

Menjatuhkan terhadap terdakwa oleh karena itu dengan pidana penjara selama 11 (sebelas) Tahun, pidana denda sebesar Rp. 100.000.000,- (seratus juta rupiah) dengan ketentuan apabila denda tersebut tidak dibayar oleh terdakwa maka akan diganti dengan pidana penjara selama 2 (dua) Bulan.

\section{DAFTAR PUSTAKA}

\section{Literatur}

Asmarawati Tina, Pidana Dan Pemidanaan Dalam Sistem Hukum Di Indonesia (Hukum Penitensier), Deepublish, Yogyakarta, 2015.

Arief Barda Nawawi, Kebijakan Legislatif dengan Pidana Penjara, Badan Penerbit UNDIP, Semarang, 1996.

Chazawi Adami, Hukum Pidana (Stelsel Pidana, Tindak Pidana, Teori-teori Pemidanaan dan Batas Berlakunya Hukum Pidana). PT. Raja Grafindo Persada : Jakarta, 2008.

Djamali Abdoel, Pengantar Hukum Indonesia, Raja Grafindo Persada, Jakarta, 1990.
Efendi Erdianto, Hukum Pidana Indonesia Suatu Pengantar, Bandung: PT Refika Aditama, 2011.

Farid A.Z Abidin, Asas-Asas Hukum Pidana Bagian 1, Bandung: Alumni, 1995.

Farid A.Z Abidin dan Hamzah Andi, Hukum Pidana Indonesia, Jakarta: PT. Yasrif Watampone, 2010.

Gultom Maidin, Perlindungan Hukum terhadap Anak dan Perempuan, PT Refika Aditama, Medan, 2012.

H.S Salim, Perkembangan Teori Dalam Ilmu Hukum, Jakarta : PT. Rajagrafindo Persada, 2012

Idries Mun'im Abdul, Pedoman Ilmu Kedokteran Forensik, Jakarta: Binarupa Aksara, 1997

Kamus Besar Bahasa Indonesia, 1995, Balai Fustaka, Jakarta.

Kansil C.S.T, Pokok-pokok Hukum Pidana Untuk Tiap-Tiap Orang, Pradnya Paramita, Bandung, 2007.

Kartini Kartono, Patologi Sosial, Bandung: CV. Rajawali, 1998.

Lamintang P.A.F, Hukum Penitensier Indonesia, Armico, Bandung, 1988, hlm 69.

Marpaung Leden, Asas-Teori-Praktik Hukum Pidana, Jakarta: Sinar Grafika, 2005

Moeljatno, Asas-Asas Hukum Pidana, Jakarta: Rineka Cipta, 1993.

Muladi dan Arief Barda Nawawi, TeoriTeori dan Kebijakan Pidana, Bandung: Alumni, 2005. 
Narbuko Cholid, Abu Achmadi, Metodologi Penelitian, Jakarta : PT. Bumi Aksara, 2013.

Prodjodikoro Wirjono, Hukum Acara Pidana di Indonesia, Sumur Bandung, Bandung, 1981.

Purnomo Bambang, Asas-asas Hukum Pidana, Jakarta : Ghalia Indonesia, 1994.

Raco. J.R, Metode Penelitian Kualitatif, Jakarta: PT Gramedia Widiasarana Indonesia, 2010

Saleh Roeslan, Stesci Pidana Indonesia, Jakarta, Aksara Barn, 1987.

Stephen Hurwitz, Kriminologi, Alih Bahasa: L. Moeljatno, Jakarta: PT Bina Aksara, 1986.

Sudarto, Hukum Dan Hukum Pidana, Alumni, Bandung, 1977.

Sugiyono, Metode Penelitian Kuantitatif, Kualitatif dan R\&D, Bandung: Alfabeta, 2009

Tongat, Hukum Pidana Materiil. UMM Press. Malang, 2006.

Tri Andrisman, Asas-Asas Dan Dasar Aturan Hukum Pidana Indonesia, Bandar Lampung, Ula, 2009.

Widnyana Made, Asas-Asas Hukum Pidana, Jakarta: Fikahati Aneska, 2010
Zed Mestika, Metode penelitian Kepustakaan, Jakarta:Yayasan Pustaka Obor Indonesia, 2014

\section{A. Perundang-undangan}

Indonesia, Undang-Undang Dasar Tahun 1945

, Kitab Undang-Undang Hukum Pidana (KUHP)

.........., Undang-Undang Nomor 35 Tahun 2014 tentang perubahan kedua atasUndang-Undang Nomor 23 Tahun 2002 tentang perlindungan anak

Undang-Undang Nomor 39 Tahun 1999 tentang hak asasi manusia

\section{B. Jurnal}

Maharani Adhyaksantari W, "Penegakan Hukum Terhadap Kasus Pembunuhan Bayi Oleh Ibu Kandungnya (Studi Kasus di Polresta Surakarta dan Polres Wonogiri)", Skripsi, Surakarta: Fakultas Hukum Universitas Muhammadiyah Surakarta, 2017, hlm. 9

Mayang Pantai Ayu Ningrum, Budi Setiyanto, Recidive Vol 3 No 2 Mei-Agustus 2014, "Analisis Tindak Pidana Pembunuhan Anak”, hlm.136-137

Nindy N. Bowonsili, "Penerapan sanksi terhadap ibu sebagai pelaku tindak pidana pembunuhan anak",Lex Crimen Vol. IV/No. 7/Sep/2015 
Fuadi Isnawan, "Analisa tindak pidana pembunuhan (infanticide) di wilayah hukum pengadilan negeri sleman", Jurnal Yuridis Vol. 5 No. 1, (2018), 23-42, http://dx.doi.org/10.35586/.v $5 i 1.315$

Jhon D. Pasalbess, "Dampak Tindak Kekerasan", Jurnal Sasi Vol.16. No.3 Bulan Juli - September 2010, hlm 10 